\title{
Migrants and Refugees in European Union: "Warm Peace", Human Rights Education and Political Sustainability
}

\author{
Manuela Magalhães ${ }^{1}$, Ana Campina ${ }^{1}$ \\ ${ }^{1}$ Associated Professor, Oporto Global University, Law Department, Researcher Integrated, IJP Portucalense Institute for \\ Legal Research, Portugal \\ Correspondence: Manuela Magalhães, Associated Professor, Oporto Global University, Law Department, Researcher \\ Integrated, IJP Portucalense Institute for Legal Research, Rua Dr. António Bernardino de Almeida, 541, 4200-072 Porto, \\ Portugal.
}

Received: September 3, 2018

Accepted: October 17, $2018 \quad$ Online Published: November 29, 2018

doi:10.11114/jets.v6i11a.3798

URL: https://doi.org/10.11114/jets.v6i11a.3798

\begin{abstract}
Nowadays European Union migrant's situation, named as a crisis, has begun during the II World War due the Holocaust. Considering the EU position and their state member facing serious Human Rights violation as well as a political complex diplomatic development (inside and outside) the European context. Holocaust has obliged millions of European citizens to "escape" from their own countries to be able to survive. The political consequences of this movement were controlled based on the diplomacy considering the war context and each state "position". Due the most different reasons, along the $20^{\text {th }}$ century the migration in, from and to Europe was an important and strong social movement but without a negative global political impact but economical. However, the last decade, especially after 2010 with the "Spring Arab" revolutions in Middle East and North Africa, Europe has been the destination of millions illegal migrants and Refugees.
\end{abstract}

Keywords:European Union, migration, human rights, international legal system, sustainability

\section{Introduction}

The European Union didn't prepare this expected reception and it's facing a dramatic human situation in all its contexts: political, social, economic, religious and cultural. In fact, there are (enough) laws and rules to protect these human beings - International, EU and each national state laws - but in some cases there are declared violations, especially Human Rights, as political and diplomatic complex relations, the non-controlled traffics (human, children, influences, interests).

The political, economic, social and including the humanitarian responsible are having serious difficulties in facing the hard realities, including the hundred deaths (the Mediterranean sea is an alive cemetery); the security questions, the reception and the integration difficulties, in the most different host countries, the society/ies behaviors; the economic and European/States budgets management being serious under the needs as well the lack of professionals enough to deal all the different and complex situations with the refuges. Consequently, the panorama is the antithesis of the Europe and EU for "all" human beings.

Although all the important and hard efforts developed by all the actors in this complex migration situation, as the several movements and changings in order to adjust the actions / available resources and capacities / spaces and work with International Organizations (governmental and non-governmental) / political and diplomatic agreements and efforts to develop International relations with origin states of the refugees, there is a more serious situation than most European citizens have knowledge. The main point is based on the absence of preparation and the consequently drama in all perspectives: the political "chain" working together to answer with the juridical, judicial and security system "concerted" within the International legal context (mainly the United Nations system) as the European Union "legal instruments". The urgent answer to the effective needs for all actors in this serious and dangerous scenery have to be based in the Human Rights system, their legal implementation and the development of their education to promote a political support, a society integration in all the demands as a collective social sustainability to implement the need measures to prevent the inherent criminality, human suffer and the illusory "warm" peace we are facing in Europe with dangerous consequences for the Humanity especially for the next generations. 


\section{Method}

The qualitative research developed, based on the historical, legal and political science perspectives, since the first moment had the main objective to identify the main problems and Human Rights, as fundamental rights, violation; the legal context and the law enforcement and the consequence judicial position. The "warm peace" we are facing and the European Union position and "behavior" (EU and their members) concerning the migrants and refugees are the perfect context to study the effective causes, to understand the serious human consequences as to identify the Public Opinion manipulation. Finally, the research method allows us to develop the perspective of the politics and political actions, within the sustainability based on the law and democratic values, toward the protection of all Human beings, including those who arrive in Europe in legal exceptional situation (illegal or Refugee) according to the United Nations System legally "signed" by the European Union.

\section{Findings}

Concerning the historical perspective, the nowadays European Union migrant's situation, named as a crisis, has begun during the II World War due the Holocaust, that we can considerer the first biggest migration and refugee's movement all around the world.

Considering the European Union position, as their 28 member states, facing serious Human Rights violation as well as a political complex diplomatic development (inside and outside) the European context. Holocaust has obliged millions of European citizens to "escape" from their own countries to be able to survive. The political consequences of this movement were controlled based on the diplomacy considering the war context and each state "position", but it's important to understand the political sustainability of that historic period was based on dictatorships and oppressive regimens who are aware of that reality but, without assuming their real position, where in connection controlling the most serious situation.

Portugal is an interesting study case, that we develop on this point of view: living a repressive regimen - Estado Novo with António de Oliveira Salazar in the political power, affirm in theory being against the migrants and refugees, but in fact there were millions arriving in the country under their control and transferred to different other countries, especially by boat. Most of the Portuguese citizens didn't have enough information (not "allowed" by the political information system completely controlled) or knowledge to identify this real situation and was completely manipulated aiming to promote the discrimination and rejection to all who would arrive from any other country. This was a serious and dangerous nationalist education, completely against the Human Rights. This had social consequences all over the $20^{\text {th }}$ century, as the democracy was implemented just in 1974 and the Human Rights Universal Declaration was recognized just in 1976 in the first Portuguese democratic Constitution. However, the social education, in the Salazar's context against all the foreigners, had results strongly negative in the Portuguese society behavior. If legally there was a crucial change with the signature (European Union and Portugal included) of the 1951 Refugee Convention as the legal document, one of the most important concerned the definition of "refugee" and the outlines of the rights of the displaced, as the legal obligations of the Stated to protect them, as well as all the Portuguese legal system, specially generated as the Refugee Statute (Law 15/98) that is a guarantee of the Asylum right to all foreigners and stateless persecuted or without freedom or surviving conditions in their own countries, it's possible to declare there are enough laws and judicial system within the United Nations and European Union idealism and needs.

And if in Europe the "warm peace" is a serious human problem, that more than political actions, demands an urgent and structured Education for Human Rights (legal obligation but not seriously implemented), there are millions of illegal migrants and Refugees facing the most different and worrying problems of violence, Human Rights and international law violation without consequences for those who promote this complex and unhuman context.

The European Union is facing this named "crisis" as a serious problem, policies controlling these movements, policing the borders, applying to international collaboration, supported in the Media to avoid the European society of the "dangerous" or the "worst" consequences" for the stability - there is information that is not aiming the Education for Human Rights but manipulate and consequently generating social and groups positions and behaviors against these unprotected human beings.

Particularly in the last year and the present one, we are assisting to several positions from the European State Members against the Illegal Migrants and Refugees reception. The Mediterranean Sea is nowadays one of the most important routes and almost a "live cemetery" considering the number of deaths everyday occurring there. Although all police control, the International Organizations - Governmental and Non-Governmental, the States control, there are millions arriving in under human conditions, from the most different reasons and from different countries, looking for surviving places (countries), mostly victims from traffic and completely lost in life. It's important to understand that in these boats, there are people with all ages and genders. They arrive in boats overbooking, without food or water, personal assets, with serious health diseases and without documents. 
However, there are too many information promoting the Public Opinion against them, with news about some "dangerous" people or "terrorists" infiltrated in these groups, not as an exception, as it is, but as the ordinary groups, what is serious concerning the consequences for the societies who are receiving them. The States where they arrive are going creating more and more hindrances for the acceptance of the Refugees in spite of being violating the international laws and all Human Rights legal system, without any international judicial consequence.

In fact, the European Union would be prepared to receive these Migration / Refugees movement, generating conditions to accomplish the laws, to protect and to promote the Human Rights, and the European Fundamental Rights, having absolutely great results - human, social, demographic, economic and political! Although all the United Nations legal system and special recommendations for this context, as well all support given in different dimensions, in fact there is a non-controlled situation, the with dramatic human situation in the refugee camps, without basic life conditions, where families are frequently separated, statements of violence, traffic (human, organs and children), placed in States member of European Union but almost as "no-man's land" where the intervention, start by the politic, legal and judicial responsible. It's urgent more than intentions but actions.

So, there is a "warm peace" - serious and dangerous situation - we are living in the European Union but unfortunately without political sustainability and needing a serious and urgent Education for Human Rights qualifying all the actors in this scenery to act to avoid human violence, suffering and all the problems connected.

\section{Conclusions}

It's true that the Migration and Refugees movement is a reality all around the world, due the most different reasons, specially wars, political system - dictatorships, oppressive, repressive regimes and the "false" democracies where there are persecutions, discrimination, racism and xenophobia are not behaviors from social groups, but actions from the governments and the political powers. Even so, the cultures and religions in double sense: the control and violence from them, and, the persecutions and violence based on those elements. Both are usually very dangerous, generating situations obliging the forced migration.

Started in $18^{\text {th }}$ December 2010, the Arab Spring - revolutionary wave (violent and non-violent) actions, protests, foreign interventions and civil wars, in North Africa and Middle East, was the best opportunity to the European Union prepare the expected migration forced, but it was not developed, as the Syria war, the worst problems with the Daesh terrorist actions and persecutions; the political, economic and social problems in the North Africa and the complex problems in Middle East, are some of the common reasons forcing migration and the huge number of Refugees arriving in Europe per day.

The reception firstly (after 2010) was made without conditions and we can affirm without structures to prepare their acceptance or verify their original situation confirming their exceptional status of Refugee, in the second phase -2012 to 2016 - there were different cooperation actions, develop of legal, judicial, police and International Organizations, based in the EU and UN laws, but with uncontrolled (hard) unhuman realities in the countries in North Africa and Middle East, the wars, economic and financial crisis, cultural and religion persecutions, violence undeclared and unjustified... this is a uncontrolled human problem that need United Nations and European Union actions and interventions. However, not only in the reception and acceptance moment, but urgently in the problematic countries from where these human beings are obliged to escape.

Considering the Right of Admission Categories - labour, family and asylum seekers and refugees the EU Blue Card Directive, the Family Reunification Directive and the Dublin Regulation are some of the most important legal instruments aiming to protect these "special" human beings. However, the European Court of Human Rights (ECtHR) is a key concern to protect legally the Human Rights, identifying the most serious problems and judge all the defaulters, although there is so many cases that the inefficient action after the judgements are so delayed or in the list to be judge that we can diagnosed inefficient results according to the real needs.

More than the rhetoric and the speeches, we need to have effective actions with positive consequences for the illegal migrants and Refugees. This valid for the States, the societies, the Organizations and the European Union, as this is a hard reality.

Reading the International Media, especially along 2018, it's easy to understand that there are happenings (the worst with serious consequences, as deaths or huge number of injuries, particularly in Mediterranean Sea, but more and more, the news are not concentrated in assume the role of information and education of societies and Public Opinion, about the real Humana drama, as the violence and Human Rights violations, but it's dealing with too much "normality", i.e., as this catastrophe is a "normal" situation in European Union.

This is a research that is a challenge as nowadays everyone speaks about it but there is less and less correct and true information, so the key is easy and not expensive: Education for Human Rights for all, as the correct knowledge, the capacity to understand the information by the Media, way to avoid violence and change social and governmental behaviors against those who are trying to survive! It's the "warm peace" ... 


\section{References}

Cunha, P. (2003). Direitos Humanos: Teorias e Práticas. Coimbra: Almedina.

Fukuyama, F. (1992). O fim da história e o último homem. Lisboa: Gradiva.

Kagan, R. (2017). "Is the democracy in decline? The Weight og Geopolitics": article in https://www.brookings.edu/articles/is-democracy-in-decline-the-weight-of-geopolitics/ accessed June 4, 2018.

Kornelsen, L. (2014). Stories of Transformation: Memories of a Global Citizenship Practicum. Canadá: ICIE.

Maalouf, A. (2009). Identidades Asesinas. Madrid: Allianza Editorial.

Maquiavel, N. (2015). O Príncipe. Lisboa: Bertrand Editora.

Marshall, T. (2016). Prisioners of Geography. London: Elliot \& Thomson.

Moury, C. (2016). A democracia na Europa. Lisboa: Fundação Francisco Manuel dos Santos.

Radu, M., \& Végh, Z. (2017). Frontiers of Democracy: Embebing Democratic Values in Central and Eastern Europe. Hungary: Central European University.

Ramonet, I. (1997). Geopolítica do caos. Rio de Janeiro: Editora Vozes.

Sartori, G. (2003). La sociedad multiétnica. Madrid: Taurus.

\section{Copyrights}

Copyright for this article is retained by the author(s), with first publication rights granted to the journal.

This is an open-access article distributed under the terms and conditions of the Creative Commons Attribution license which permits unrestricted use, distribution, and reproduction in any medium, provided the original work is properly cited. 